\title{
ORIENTASI PASAR DAN INOVASI PRODUK PENGARUHNYA TERHADAP KINERJA PEMASARAN DENGAN VARIABEL INTERVENING KEUNGGULAN BERSAING PADA UMKM KECAMATAN KALIWATES
}

\author{
ACHADYAH PRABAWATI* \\ MELIA HANDAYANI \\ Program Studi Ilmu Administrasi Niaga \\ Sekolah Tinggi Ilmu Administrasi Pembangunan Jember \\ *Email: achadyahprabawati@gmail.com
}

\begin{abstract}
ABSTRAK
Penelitian ini menganalisis pengaruh orientasi pasar dan inovasi produk terhadap kinerja pemasaran dengan keunggulan bersaing sebagai variabel intervening. Objek penelitian dari penelitian ini adalah pengusaha UMKM yang berada di Kecamatan Kaliwates Kabupaten Jember terutama UMKM yang bergerak di bidang makanan khusunya UMKM yang melakukan inovasi produk. Populasi pada penelitian ini sebanyak 49 UMKM yang bergerak dibidang makanan. Pengambilan sampel pada penelitian ini menggunakan sampling jenuh yaitu sebanyak 49 UMKM. Analisis yang digunakan pada penelitian ini adalah analisis intervening (path analysis) dengan menggunakan software IBM SPSS 22.0. Terdapat tujuh hipotesis yang digunakan, dimana terdapat satu hipotesis yang tidak diterima dan tidak signifikan dan enam hipotesis diterima. Berdasarkan hasil penelitian, hipotesis yang tidak diterima dan tidak signifikan yaitu variabel inovasi produk terhadap keunggulan bersaing. Berdasarkan pengaruh langsung dan tidak langsung kedua jalur berpengaruh, namun terdapat jalur yang berpengaruh namun tidak signifikan yaitu variabel inovasi produk terhadap kinerja pemasaran melalui keunggulan bersaing. Sedangkan jalur dari variabel orientasi pasar terhadap kinerja pemasaran melalui keunggulan bersaing berpengaruh dan signifikan.
\end{abstract}

Kata Kunci: Orientasi Pasar, Inovasi Produk, Keunggulan Bersaing, Kinerja Pemasaran. 


\section{PENDAHULUAN}

Di Indonesia, kita mengenal Secara umum keberadaan UMKM di adanya Usaha Mikro, Kecil dan Menengah (UMKM) yang Indonesia dapat dikatakan sebagai berkontribusi besar pada proses pemerataan dan peningkatan tulang punggung perekonomian masyarakat Indonesia. Berikut data perkembangan UMKM dari tahun pendapatan masyarakat Indonesia. 2012-2013.

Tabel 1. Data Perbandingan Industri Mikro Dan Kecil Dengan Usaha Besar Dari Tahun 2013-2015

\begin{tabular}{|l|r|r|r|}
\hline \multicolumn{1}{|c|}{ Tahun } & \multicolumn{1}{c|}{$\mathbf{2 0 1 3}$} & \multicolumn{1}{c|}{$\mathbf{2 0 1 4}$} & \multicolumn{1}{c|}{$\mathbf{2 0 1 5}$} \\
\hline Industri & & & \\
\hline Mikro & 2.887 .015 & 3.220 .563 & 3.385 .851 \\
\hline Kecil & 531.351 & 284.501 & 283.022 \\
\hline Besar & 23.698 & 24.529 & 26.322 \\
\hline Total & $\mathbf{3 . 4 4 2 . 0 6 4}$ & $\mathbf{3 . 5 2 9 . 5 9 3}$ & $\mathbf{3 . 6 9 5 . 1 9 5}$ \\
\hline
\end{tabular}

Sumber: Badan Pusat Statistik

Berdasarkan Tabel 1. maka dapat diartikan bahwa industri Mikro Kecil di Indonesia mengalami peningkatan dari tahun ke tahun. Jika dibandingkan dengan industri besar atau usaha besar yang ada di Indonesia memiliki jumlah usaha lebih sedikit dibandingkan dengan industri Mikro Kecil. Dengan jumlah UMKM yang tersebar di Indonesia membuktikan bahwa UMKM memiliki proporsi yang besar dalam total keseluruhan pelaku usaha di Indonesia.
Dalam mendapatkan pasar, UMKM pada umumnya harus mampu menjalankan beberapa alternatif strategi. Strategi perusahaan selalu diarahkan untuk menghasilkan kinerja, baik kinerja keuangan maupun kinerja pemasaran. Pemasaran sangat penting bagi setiap perusahaan apa lagi ditambah dengan adanya tekanan dari persaingan yang begitu ketat, dapat memengaruhi kinerja pemasaran baik secara langsung maupun tidak langsung. Kinerja 
pemasaran bukan semata-mata sebagai alat tawar menawar antar pembeli dan penjual, akan tetapi bentuk tanggung jawab bidang pemasaran untuk dapat mengkomunikasikan fokus jangka panjangnya Sarjita (2017).

Kebutuhan pasar atau orientasi pasar merupakan ukuran perilaku dan aktivitas yang mencerminkan implementasi konsep pemasaran Tjiptono (2008). Kondisi pasar mengalami berbagai perubahan dimana perubahan tersebut menuntut adanya inovasi yang dapat mengembangkan suatu produk untuk mempertahankan kelangsungan hidup dan keuntungan perusahaan Tjiptono (2008).

Kabupaten Jember merupakan daerah yang cukup potensial karena memiliki jumlah UMKM yang cukup banyak yaitu sebanyak 2.674 UMKM dimana Kecamatan Kaliwates memiliki 326 UMKM. UMKM akan tetap beroperasional apabila UMKM mampu berinovasi.

Potensi jumlah UMKM yang besar harus dapat dimanfaatkan sehingga UMKM di Jember menjadi organisasi yang memiliki daya saing yang tinggi. UMKM haruslah memiliki beberapa strategi usaha, yaitu dengan melihat orientasi pasarnya, memperbaiki inovasi produknya, serta memiliki keunggulan bersaingnya.

Sehingga dengan adanya tiga faktor tersebut UMKM dapat meningkatkan kinerja pemasaran. Ada beberapa bukti empiris yang menunjukkan bahwa kinerja pemasaran dipengaruhi oleh orientasi pasar, inovasi produk, serta keunggulan bersaing (Merakati et al (2017); Basuki dan Widayanti (2014); Djojobo dan Hendra (2016); dan Putra dan Rahanatha (2017) ).

Selain itu permasalahan yang terjadi di Jember terletak bagaimana pengusaha bisnis belum sepenuhnya sadar bahwa pemasaran sangatlah penting dalam meningkatkan kinerja pemasaran. Berdasarkan observasi dan wawancara dengan beberapa pelaku usaha UMKM di Kecamatan Kaliwates, menunjukkan bahwa UMKM yang ada masih perlu melakukan banyak pengembangan untuk dapat meningkatkan keunggulannya dalam persaingan bisnis. 
Misalnya dalam orientasi pasar, banyak UMKM yang belum memperhatikan apa yang diinginkan konsumen, untuk inovasi produk pelaku UMKM masih harus banyak belajar mengenai pentingnya berinovasi dalam persaingan bisnis. Dimana dengan berinovasi membuat produk yang sudah lama dikenal menjadi lebih berbeda. Hal seperti itu masih belum sepenuhnya diterapkan pada setiap UMKM. Meskipun banyak UMKM di Kecamatan Kaliwates para pelaku

\section{TINJAUAN PUSTAKA}

\subsection{Manajemen Pemasaran}

Menurut Assauri (2013:12) manajemen pemasaran merupakan kegiatan penganalisisan, perencanaan, pelaksanaan, dan pengendalian program-program yang dibuat untuk membentuk, membangun, dan memelihara keuntungan dari pertukaran melalui sasaran pasar guna mencapai tujuan organisasi (perusahaan) dalam jangka panjang. Sedangkan menurut Kotler (2005:9) manajemen pemasaran adalah proses perancanaan dan pelaksanaan,
UMKM belum bisa memiliki keunggulan bersaingnya apalagi ditengah persaingan bisnis yang semakin ketat.

Berdasarkan uraian permasalahan diatas, peneliti tertarik untuk melakukan penelitian dengan judul "Orientasi Pasar dan Inovasi Produk Pengaruhnya terhadap Kinerja Pemasaran dengan Variabel Intervening Keunggulan Bersaing pada UMKM Kecamatan Kaliwates".

pemikiran, penetapan harga promosi, serta penyaluran gagasan barang dan jasa untuk menciptakan pertukaran yang memenuhi sasaran-sasaran individu dalam organisasi.

Berdasarkan pendapat dari beberapa ahli maka dapat disimpulkan bahwa manajemen pemasaran merupakan kegiatan penganalisisan, perencanaan dan pemikiran yang dilakukan organisasi atau perusahaan untuk mancapai tujuan dari organisasi atau perusahaan. 


\subsection{Orientasi Pasar}

Orientasi pasar didefinisikan sebagai perilaku organisasi yang mengedentifikasikan kebutuhan konsumen, perilku kompetitor, menyebarkan informasi pasar keseluruh organisasi dan meresponnya dengan suatu koordinasi, perhitungan waktu, dan perhitungan keuntungan. Menurut Kotler dan Amstrong (2008) orientasi pasar adalah untuk memenuhi kebutuhan dan keinginan pelanggan, saran lebih efektif dan efisien dari pada pesaing untuk menentukan pemenuhan tujuan perusahaan. Pandangan kedua, mengklaim bahwa jika suatu perusahaan berorientasi pada pasar, resiko kegagalan terkurangi.

Melihat pendapat dari beberapa ahli diatas maka dapat disimpulkan bahwa orientasi pasar merupakan budaya organisasi yang paling efektif dalam menciptakan perilaku penting untuk penciptaan nilai unggu bagi pembeli serta kinerja dalam bisnis.

\subsection{Inovasi Produk}

Menurut Kotler \& Keller (2007), inovasi produk adalah gabungan dari berbagai macam proses yang saling mempengaruhi antara yang satu dengan yang lain. Serta menurut (Tjiptono,2008), produk baru berperan penting dalam meningkatkan profitabilitas perusahaan. Sementara inovasi proses memainkan peran sebagai strategi dalam menekankan biaya.

Inovasi produk merupakan produk atau jasa baru yang diperkenalkan pada pasar. Inovasi produk dikategorikan sebagai produk baru bagi dunia, lini produk baru, tambahan pada lini produk baru, tambahan pada lini produk baru yang telah ada, perbaikan dan revisi produk yang telah ada, penentuan kembali dan pengurangan biaya (Nasution,2005).

\subsection{Keunggulan Bersaing}

Menurut Kotler (2005: 68) keunggulan bersaing adalah keunggulan atas pesaing yang didapatkan dengan menyampaikan nilai pelanggan yang lebih besar, melalui harga yang lebih murah atau dengan menyediakan lebih banyak manfaat yang sesuai dengan penetapan harga yang lebih tinggi. 
Menurut Dirgantoro (2001:159) bahwa, keunggulan bersaing merupakan perkembangan dari nilai yang mampu diciptakan perusahaan untuk pembelinya. Sesuatu yang memungkinkan sebuah perusahaan memperoleh keuntungan yang lebih tinggi dibandingkan dengan rata-rata keuntungan yang diperoleh pesaing dalam industri. Semakin kuat keunggulan yang dimiliki akan semakin tinggi keuntungan yang diperoleh perusahaan dan begitu pula sebaliknya.

\subsection{Kinerja Pemasaran}

Kinerja pemasaran merupakan ukuran prestasi yang diperoleh dari aktivitas proses pemasaran secara menyeluruh dari sebuah perusahaan atau organisasi. Menurut Ferdinand (2000) menyatakan bahwa kinerja pemasaran merupakan faktor yang seringkali digunakan untuk mengukur dampak dari strategi yang diterapkan perusahaan yang baik dan juga kinerja keuangan yang baik.

Kinerja organisasi terdiri dari kinerja pemasaran, kinerja keuangan, dan kinerja sumber daya manusia. Strategi perusahaan selalu diarahkan untuk menghasilkan kinerja pemasaran yaitu volume penjualan, market share, dan pertumbuhan penjualan dan kinerja perusahaan sebagai usaha pengukuran tingkat kinerja meliputi omzet penjualan, jumlah pembeli, keuntungan dan pertumbuhan penjualan (Ferdinand, 2000).

\subsection{Kerangka Pemikiran}

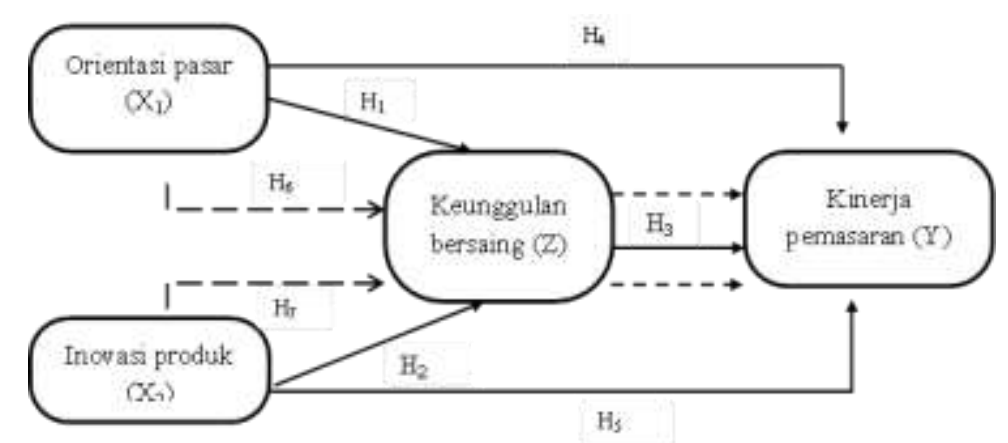

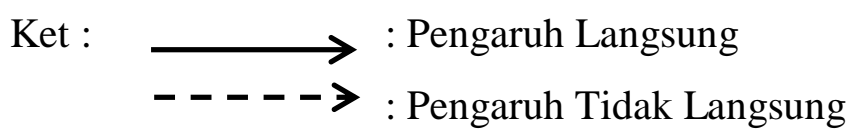

Gambar 1. Kerangka Pemikiran 


\subsection{Hipotesis Penelitian}

$\mathrm{H}_{1}$ : Orientasi pasar berpengaruh terhadap keunggulan bersaing.

$\mathrm{H}_{2}$ : Inovasi produk berpengaruh terhadap keunggulan bersaing.

$\mathrm{H}_{3}$ : Keunggulan bersaing berpengaruh terhadap kinerja pemasaran.

$\mathrm{H}_{4}$ : Orientasi pasarberpengaruh terhadap kinerja pemasaran.

\section{METODE PENELITIAN}

Dalam penelitian ini yang digunakan adalah metode penelitian kuantitaif. Unit analisis dalam penelitian ini adalah organisasi yang dalam hal ini diwakili oleh pemilik/ pimpiman/manajer UMKM. Tempat atau lokasi penelitian yang dilakukan oleh peneliti yaitu UMKM bergerak dibidang makanan yang berada di Kabupaten Jember khususnya Kecamatan Kaliwates. Peneliti memilih tempat ini dikarenakan di Kecamatan Kaliwates jumlah UMKM lumayan banyak yaitu 326 UMKM. Pada penelitian ini, Populasi yang diambil adalah UMKM yang telah melakukan inovasi dan masih eksis. Sebanyak
$\mathrm{H}_{5}$ : Inovasi produk berpengaruh terhadap kinerja pemasaran.

$\mathrm{H}_{6}$ : Orientasi pasar berpengaruh terhadap kinerja pemasaran melalui keunggulan bersaing.

$\mathrm{H}_{7}$ : Inovasi produk berpengaruh terhadap kinerja pemasaran melalui keunggulan bersaing.

104 UMKM hanya 49 UMKM yang melakukan inovasi dan tetap eksis.

Metode yang digunakan dalam pengambilan sampel ini adalah purposive sampling. Sedangkan untuk teknik pengambilan sampling, penelitian ini menggunakan teknik sampling jenuh. Sampel yang diambil adalah seluruh UMKM yang bergerak dibidang makanan, di Kecamatan Kaliwates Kabupaten Jember khusunya yang melakukan inovasi produk dan tetap eksis sebanyak 49 UMKM.

Jenis data yang digunakan pada penelitian ini adalah jenis data interval. Sumber data yang digunakan yaitu data primer dan sekunder. Data primer yang 
digunakan pada penelitian ini berasal dari kuesioner yang dibagikan dan diisi oleh pimpinan UMKM sektor manufaktur yang bergerak dibidang makanan Kecamatan Kaliwates, Kabupaten Jember. Sedangkan Data Sekunder yang digunakan pada penelitian ini adalah data yang berasal dari data Dinas Koperasi dan UMKM yang berupa data UMKM yang terdapat di Kabupaten Jember.
Variabel yang digunakan dalam penelitian ini meliputi variabel independen $(\mathrm{X})$ yaitu orientasi pasar $\left(\mathrm{X}_{1}\right)$, inovasi produk $\left(\mathrm{X}_{2}\right)$ Kemudian variabel interveing (Z) yaitu keunggulan bersaing dan variabel dependen (Y) yaitu kinerja pemasaran. Analisis data yang digunakan yaitu analisis deskriptif meliputi deskripsi responden, kemudian analisis inferensial yaitu analisis jalur (path analysis).

\section{HASIL PENELITIAN DAN PEMBAHASAN}

\subsection{Hasil Penelitian}

Berdasarkan hasil uji validitas seluruh item variabel memiliki nilai koefisien lebih dari 0,2816, dan berdasarkan uji reliabilitas nilai koefisien cronbach Alpha seluruh variabel lebih dari 0,6. Sehingga item pernyataan seluruh varaibel valid dan reliabel.

Berdasarkan deskripsi umum responden dapat diketahui bahwa UMKM di Kecamatan Kaliwates memiliki pimpinan atau pemiliki perempuan dengan jumlah responden $33(67 \%)$, Pendidikan terakhir yang ditempuh yaitu SMA dengan jumlah $18(37 \%)$, lama menjalankan usaha yaitu 6-8 tahun dengan jumlah 20 (41\%) dan yang terakhir umur responden mayoritas 31-40 tahun dengan jumlah 19 (39\%).

Pada penelitian ini data diolah dengan uji asumsi klasik yang meliputi uji normalitas, uji heteroskedastisitas dan uji multikolinieritas. Berdasarkan hasil SPSS penelitian ini berdistribusi normal, bebas heteroskedastisitas, dan tidak terjadi multikolinieritas. Penelitian ini juga menggunakan uji hipotesis yang menggunkan uji $\mathrm{F}$ dan uji t, dimana terdapat dua model yang akan ditampilkan pada Tabel 2 dan 3. 
Tabel 2. Hasil Uji F

\begin{tabular}{|c|l|c|c|c|}
\hline Model & \multicolumn{1}{|c|}{ Variabel } & $\mathrm{F}_{\text {hitung }}$ & $\mathrm{F}_{\text {tabel }}$ & Sig \\
\hline I. & $\begin{array}{l}\text { Orientasi Pasar, Inovasi Produk, terhadap } \\
\text { Keunggulan Bersaing }\end{array}$ & 4,560 & 2,82 & 0,016 \\
\hline II. & $\begin{array}{l}\text { Orientasi Pasar, Inovasi Produk, Keunggulan } \\
\text { Bersaing, terhadap Kinerja Pemasaran }\end{array}$ & 17,619 & 2,81 & 0,000 \\
\hline
\end{tabular}

Sumber: Pengolahan data SPSS 22.0

Pada Tabel 2 terlihat bahwa Terlihat bahwa nilai $F_{\text {hitung }}>F_{\text {tabel }}$ semua model memiliki pengaruh dan nilai Sig. lebih kecil dari 0,05. secara simultan dan signifikan.

Tabel 3. Hasil Uji t

\begin{tabular}{|c|l|c|c|c|c|}
\hline Model & \multicolumn{1}{|c|}{ Variabel } & Ket & $t_{\text {hitung }}$ & $t_{\text {tabel }}$ & Sig \\
\hline \multirow{2}{*}{ I. } & Orientasi Pasar, Inovasi Produk & $\mathrm{OP} \rightarrow \mathrm{KB}$ & 2,358 & 1,679 & 0,023 \\
\cline { 3 - 6 } & terhadap Keunggulan Bersaing & $\mathrm{IP} \rightarrow \mathrm{KB}$ & 1,567 & 1,679 & 0,125 \\
\hline \multirow{2}{*}{ II. } & Orientasi Pasar, Inovasi Produk, & $\mathrm{OP} \rightarrow \mathrm{KP}$ & 2,737 & 1,679 & 0,009 \\
\cline { 3 - 6 } & Keunggulan Bersaing, terhadap & $\mathrm{IP} \rightarrow \mathrm{KP}$ & 4,259 & 1,679 & 0,000 \\
\cline { 3 - 6 } & Kinerja Pemasaran & $\mathrm{KB} \rightarrow \mathrm{KP}$ & 2,715 & 1,679 & 0,009 \\
\hline
\end{tabular}

Sumber: Pengolahan data SPSS 22.0

Pada uji t hipotesis diterima jika nilai $t_{\text {hitung }}>t_{\text {tabel }}$ dan nilai sig. lebih kecil dari 0,05. Berdasarkan Tabel 3 nilai t masing-masing model yaitu :

1. Orientasi pasar terhadap keunggulan bersaing berpangruh signifikan, maka $\mathrm{H}_{1}$ diterima.

2. Inovasi produk terhadap keunggulan bersaing tidak berpengaruh signifkan, maka $\mathrm{H}_{2}$ ditolak.

3. Orientasi pasar terhadap kinerja pemasaran berpengaruh signifikan, maka $\mathrm{H}_{4}$ diterima.
4. Inovasi produk terhadap kinerja pemasaran berpengaruh signifikan, maka $\mathrm{H}_{5}$ diterima.

5. Keunggulan bersaing terhadap kinerja pemasaran berpengaruh signifikan, maka $\mathrm{H}_{3}$ diterima.

Berikutnya untuk uji analisis data peneliti menggunakan analisis intervening (path analysis). Berikut akan disajikan Tabel 4 pengaruh langsung variabel dependen terhadap variabel independen. 
Tabel 4. Hasil Analisis Jalur Pengaruh Langsung Variabel Independen Terhadap Variabel Dependen

\begin{tabular}{|l|c|c|}
\hline \multicolumn{1}{|c|}{ Variabel } & Beta & Sig. \\
\hline Orientasi Pasar $\left(\mathrm{X}_{1}\right) \rightarrow$ Keunggulan Bersaing $(\mathrm{Z})$ & 0,320 & 0,023 \\
\hline Inovasi Produk $\left(\mathrm{X}_{2}\right) \rightarrow$ Keunggulan Bersaing $(\mathrm{Z})$ & 0,213 & 0,125 \\
\hline Keunggulan bersaing $(\mathrm{Z}) \rightarrow$ Kinerja Pemasaran $(\mathrm{Y})$ & 0,300 & 0,009 \\
\hline Orientasi Pasar $\left(\mathrm{X}_{1}\right) \rightarrow$ Kinerja Pemasaran $(\mathrm{Y})$ & 0,295 & 0,009 \\
\hline Inovasi Produk $\left(\mathrm{X}_{2}\right) \rightarrow$ Kinerja Pemasaran $(\mathrm{Y})$ & 0,446 & 0,000 \\
\hline
\end{tabular}

Sumber: Pengolahan data SPSS 22.0

Pada Tabel 4. terlihat bahwa ada satu jalur pengaruh langsung yang tidak berpengaruh dan tidak signifikan yaitu variabel inovasi produk terhadap kinerja pemasaran dengan beta 0,213 dan signifikansi 0,125 yang lebih besar dari 0,05 . Berdasarkan data pengaruh langsung diatas maka dapat diketahui untuk mencari pengaruh tidak langsung dan total pengaruh variabel independen terhadap variabel dependen dengan perhitungan sebagai berikut :

1. Pengaruh variabel orentasi pasar $\left(\mathrm{X}_{1}\right)$ terhadap kinerja pemasaran (Y). Pengaruh Langsung : 0,295

Pengaruh tidak langsung : 0,320 x $0,300=0,096$

Total Pengaruh: 0,295 $+0,096=$ 0,391

Pengaruh langsung sebesar 0,295 lebih kecil dari pengaruh tidak langsung sebesar 0,391. Hal ini menunjukkan bahwa hipotesa enam $\left(\mathrm{H}_{6}\right)$ diterima.

2. Pengaruh variabel inovasi produk $\left(\mathrm{X}_{2}\right)$ terhadap kinerja pemasaran (Y). Pengaruh langsung : 0,446

Pengaruh tidak langsung : 0,213 x $0,300=0,064$

Total pengaruh : $0,446+0,064=$ 0,510

Pengaruh langsung sebesar 0,446 lebih kecil dari pengaruh tidak langsung sebesar 0,510. Hal ini menunjukkan bahwa hipotesa tujuh $\left(\mathrm{H}_{7}\right)$ diterima.

\subsection{Pembahasan}

1. Orientasi pasar terhadap keunggulan bersaing

Penelitian ini menunjukkan bahwa hipotesis pertama $\left(\mathrm{H}_{1}\right)$ diterima. Dimana hipotesis pertama $\left(\mathrm{H}_{1}\right)$ yaitu orientasi pasar berpengaruh terhadap keunggulan bersaing. Penelitian 
ini menunjukkan bahwa nilai $t_{\text {hitung }}>t_{\text {tabel }}$ sehingga peneliti menyimpulkan bahwa keunggulan bersaing UMKM akan meningkat jika variabel orientasi pasar meningkat.

Jika dilihat berdasarkan perspektif empiris, penelitian ini sejalan dengan hasil penelitian sebelumnya yang dilakukan oleh Basuki dan Widyanti (2014). Berdasarkan hasil analisis deskriptif responden memperlihatkan bahwa sebagian besar pemimpin yang mengisi kuisioner penelitian ini didominasi oleh pemimpin yang memiliki rentang usia $31-40$ tahun sebesar 19 orang dengan persentase $35 \%$, data tersebut menunjukkan bahwa pemimpin UMKM masih tergolong muda dalam menjalankan bisnisnya. berdasarkan pengamatan yang telah dilakukan peneliti, UMKM di kcamatan kaliwates sudah cukup baik dalam menempatkan pasar sebagai fokus utama bagi perusahaan.

\section{Inovasi produk terhadap}

\section{keunggulan bersaing}

Penelitian ini menunjukkan bahwa hipotesis dua $\left(\mathrm{H}_{2}\right)$ ditolak. Dimana hipotesis dua $\left(\mathrm{H}_{2}\right)$ yaitu inovasi produk tidak berpengaruh terhadap keunggulan bersaing. Penelitian ini menunjukkan bahwa nilai $t_{\text {hitung }}<t_{\text {tabel }}$ sehingga peneliti menyimpulkan bahwa keunggulan bersaing tidak akan mengalami peningkatatan ataupun penururnan walaupun inovasi produk mengalami perubahan.

Jika dilihat berdasarkan perspektif empiris, penelitian ini tidak sejalan dengan hasil penelitian sebelumnya yang dilakukan oleh Djojobo dan Hendra (2014). Dimana pada penelitian terdahulu menunjukkan bahwa inovasi produk memiliki pengaruh yang positif terhadap keunggulan bersaing.

Berdasarkan pengamatan lapangan, UMKM kecamatan Kaliwates terutama yang bergerak dibidang makanan harus dapat meningkatkan inovasi pada produknya, dengan 
sedikitnya pengetahuan tentang pentingnya berinovasi membuat produk UMKM belum mampu bersaing dengan para pesaingnya.

\section{Keunggulan}

bersaing

\section{terhadap kinerja pemasaran}

Penelitian ini menunjukkan bahwa hipotesis tiga $\left(\mathrm{H}_{3}\right)$ diterima. Dimana hipotesis tiga $\left(\mathrm{H}_{3}\right)$ yaitu keunggulan bersaing berpengaruh terhadap kinerja pemasaran.

Penelitian ini menunjukkan bahwa nilai $t_{\text {hitung }}>t_{\text {tabel }}$ sehingga peneliti menyimpulkan bahwa kinerja pemasaran akan meningkat jika variabel keunggulan bersaing meningkat.

Jika dilihat dari perspektif empiris penelitian ini sejalan dengan penelitian yang dilakukan oleh Pattipeilohy (2018) dan Dewi (2017) juga menjelaskan bahwa keunggulan bersaing berpengaruh positif dan signifikan terhadap keunggulan bersaing.

Suatu UMKM dapat mempertahankan ataupun meningkatkan keunggulannya jika UMKM telah lama menjalankankan usahanya. UMKM yang telah lama menjalankan usahanya mampu mengenali keunggulan yang dimiliki perusahaannya.

\section{Orientasi pasar terhadap} kinerja pemasaran

Penelitian ini menunjukkan bahwa hipotesis empat $\left(\mathrm{H}_{4}\right)$ diterima. Dimana hipotesis empat $\left(\mathrm{H}_{4}\right)$ yaitu orientasi pasar berpengaruh terhadap kinerja pemasaran. Penelitian ini menunjukkan bahwa nilai $t_{\text {hitung }}$ $>t_{\text {tabel }}$ sehingga peneliti menyimpulkan bahwa kinerja pemasaran akan meningkat jika variabel orientasi pasar meningkat.

Jika dilihat berdasarkan perspektif empiris, penelitian ini sejalan dengan hasil penelitian sebelumnya yang dilakukan oleh Lapian et al (2016) dan Dewi (2017). Dimana pada penelitian terdaahulu menunjukkan bahwa orientasi pasar berpengaruh terhadap kinerja pemasaran.

Berdasarkan pengamatan
dilakukan dilapangan,


UMKM Kecamatan Kaliwates sudah baik dalam menangani para pesaingnya dan mampu mebuat pelanggan puas dengan produk yang ditawarkan.

\section{Inovasi produk terhadap}

\section{kinerja pemasaran}

Penelitian ini menunjukkan bahwa hipotesis lima $\left(\mathrm{H}_{5}\right)$ diterima. Dimana hipotesis lima $\left(\mathrm{H}_{5}\right)$ yaitu inovasi produk berpengaruh terhadap kinerja pemasaran. Penelitian ini menunjukkan bahwa nilai $t_{\text {hitung }}$ $>t_{\text {tabel }}$ sehingga peneliti menyimpulkan bahwa kinerja pemasaran akan meningkat jika variabel inovasi produk meningkat.

Jika dilihat dari perspektif empiris penelitian ini sejalan dengan penelitian yang dilakukan oleh Lapian et al (2018) dan Pattipeilohy (2018). Penelitian terdahulu membuktikan bahwa variabel inovasi produk berpengaruh signifikan terhadap kinerja pemasaran.

Berdasarkan pengamatan lapangan, UMKM di Kecamatan
Kaliwates yang begerak dibidang makanan, mampu meningkatkan kinerja pemasaran dengan melakukan inovasi pada produknya.

Misalnya untuk produk kue, biasanya para pelaku UMKM membuat berbagai inovasi pada bentuknya ataupun ukurannya sehingga pelanggan tertarik akan produk yang ditawarkan sehingga hal tersebut dapat meningkatkan kinerja pemasaran UMKM.

6. Orientasi Pasar Terhadap Kinerja Pemasaran Melalui

\section{Keunggulan Bersaing}

Penelitian ini menunjukkan bahwa hipotesis enam $\left(\mathrm{H}_{6}\right)$ diterima. Dimana hipotesis enam $\left(\mathrm{H}_{6}\right)$ yaitu orientasi pasar berpengaruh terhadap kinerja pemasaran melalui keunggulan bersaing. Penelitian ini menunjukkan bahwa nilai pengaruh langsung lebih kecil dari pengaruh tidak langsung (pengaruh langsungnya sebesar 0,295 dan pengaruh tidak langsungnya sebesar 0,391) sehingga peneliti menyimpulkan 
bahwa kinerja pemasaran akan meningkat jika orientasi pasar meningkat melalui keunggulan bersaing.

Jika dilihat berdasarkan perspektif empiris, penelitian ini sejalan dengan hasil penelitian sebelumnya yang dilakukan oleh Dewi (2017). Dimana pada penelitian terdahulu menunjukkan bahwa orientasi pasar berpengaruh terhadap kinerja pemasaran melalui keunggulan bersaing.

Kontribusi yang diberikan keunggulan bersaing mampu menjadi mediasi yang memberikan pengaruh total yang lebih besar antara orientasi pasar terhadap kinerja pemasaran.

\section{Inovasi Produk Terhadap} Kinerja Pemasaran Melalui Keunggulan Bersaing

Penelitian ini menunjukkan bahwa hipotesis tujuh $\left(\mathrm{H}_{7}\right)$ diterima. Dimana hipotesis tujuh $\left(\mathrm{H}_{7}\right)$ yaitu inovasi produk berpengaruh terhadap kinerja pemasaran melalui keunggulan bersaing. Penelitian ini menunjukkan bahwa nilai pengaruh langsung lebih kecil dari pengaruh tidak langsung (pengaruh langsungnya sebesar 0,446 dan pengaruh tidak langsungnya sebesar 0,510) sehingga peneliti menyimpulkan bahwa kinerja pemasaran akan meningkat jika inovasi produk meningkat melalui keunggulan bersaing.

Jika dilihat berdasarkan perspektif empiris, penelitian ini sejalan dengan hasil penelitian sebelumnya yang dilakukan oleh Prakoso (2005). Dimana pada penelitian terdahulu menunjukkan bahwa inovasi produk berpengaruh terhadap kinerja pemasaran melalui keunggulan bersaing.

Berdasarkan pengamatan lapangan, UMKM di Kecamatan Kaliwates yang begerak dibidang makanan, mampu meningkatkan kinerja pemasaran dengan meningkatkan inovasi produk melalui keunggulan bersaing.

Kontribusi yang diberikan keunggulan bersaing mampu menjadi mediasi yang 
memberikan pengaruh total yang lebih besar antara inovasi

\section{KESIMPULAN DAN SARAN}

\subsection{Kesimpulan}

Berdasarkan hasil penelitian sebelumnya dapat dismpulan bahwa secara keseluruhan, dari tujuh hipotesis yang diajukan dalam penelitian ini terdapat enam hipotesis yang diterima dan satu hipotesis yang tidak diterima yaitu :

1. $\mathrm{H}_{1}$ diterima, dimana variabel orientasi pasar (X1) berpengaruh positif dan signifikan terhadap keunggulan bersaing (Z).

2. $\mathrm{H}_{2}$ ditolak, dimana variabel inovasi produk (X2) tidak berpengaruh signifikan terhadap keunggulan bersaing $(\mathrm{Z})$.

3. $\mathrm{H}_{3}$ diterima, dimana variabel keunggulan bersaing (Z) berpengaruh positif dan signifikan terhadap kinerja pemasaran $(\mathrm{Y})$.

4. $\mathrm{H}_{4}$ diterima, dimana variabel orientasi pasar (X1) berpengaruh positif dan produk terhadap kinerja pemasaran.

signifikan terhadap kinerja pemasaran (Y).

5. $\mathrm{H}_{5}$ diterima, dimana variabel inovasi produk (X2) berpengaruh positif dan signifikan terhadap kinerja pemasaran (Y).

6. $\mathrm{H}_{6}$ diterima, dimana variabel orientasi pasar (X1) berpengaruh positif dan signifikan terhadap kinerja pemasaran (Y) melalui keunggulan bersaing (Z).

7. $\mathrm{H}_{7}$ diterima, dimana variabel inovasi produk (X2) berpengaruh positif namun tidak signifikan terhadap kinerja pemasaran melalui keunggulan bersaing (Z).

\subsection{Saran}

Berdasarkan temuan penelitian maka dapat dikemukakan saran-saran sebagai berikut:

1. Bagi UMKM lebih memperhatikan variabel 
yang mempengaruhi kinerja pemasaran baik langsung maupun tidak langsung.

2. Bagi penelitian selanjutnya diharapkan menggunakan sampel yang lebih banyak, cakupan lokasi yang lebih

\section{DAFTAR PUSTAKA}

\section{Buku}

Assauri, Sofjan. 2013. Manajemen Pemasaran. Jakarta: Rajawali Pers.

Dirgantoro, Crown. 2001. Manajemen Stratejik : Konsep, Kasus, dan Implementasi. Jakarta: Grasindo.

Ferdinand, Augusty. 2000. Strategic Selling in Management. Semarang: Universitas Diponegoro.

Kotler, Philip. 2005. Manjemen Pemasaran. Jakarta: PT. Indeks. , and Kevin L. Keller. 2007. Manajemen Pemasaran. Jilid 1. Edisi 12. Jakarta : Indeks. , Philip dan Armstrong, Gary. 2008. Principle Of Marketing. $10^{\text {th }}$ edition. New Jersey: Pearson Education.

Nasution, M.N. 2005. Total Quality Management. Jakarta : PT Ghalia Indonesia.

Tjiptono, Fandy. 2008. Strategi Pemasaran. Edisi 3. Yogyakarta : ANDI luas, memilih UMKM sektor lain, menambahkan variabel lain yang berpengaruh terhadap keunggulan bersaing dan kinerja pemasaran seperti variabel orientasi kewirausahaan.

\section{Jurnal}

Basuki, dan Widyanti, Rahmi. 2014. Pengaruh Startegi Keunggulan Bersaing dan Orientasi Pasar Terhadap Kinerja Pemsaran Perusahan. Universitas Islam Kalimantan Banjarmasin. Jurnal Ekonomi dan Bisnis UNISKA Banjarmasin. Vol. 2 No. 2. Hal.1-14.

Dewi, Ni Made Putri. 2017. Peran Keunggulan Bersaing dalam Memediasi Pengaruh Orientasi Pasar Terhadap Kinerja Pemasaran. E-Jurnal Manajemen UNUD. Vol. 6. No. 9. Hal. 4947-4977.

Djojobo, Cynthia Vanessa, dan Hendra. 2014. Pengaruh Orientasi Kewirausahaan, Inovasi Produk, Dan Keunggulan Bersaing Terhadap Kinerja Pemasaran Usaha Kuning Di Kota Manado. Universitas Sam Ratulangi Manado. Jurnal Riset, Ekonomi, Manajemen Bisnis dan Akutansi. Vol.2 No.3. Hal. 1214-1224. 
Hartanti, Irfanunnisa' Tsalits, dan Ratnawati, Alifah. 2013. Peningkatan Kinerja Pemasaran Melalui Optimalisasi Keunggulan Bersaing. Jurnal Ekonomi dan Bisnis. Vol. 14. No. 2. Hal. 72-89.

Lapian, Adelina Agne. Massie ,James dan Ogi, Imelda. 2016. Pengaruh orientasi pasar, inovasi produk terhadap kinerja pemasaran pada PT.BPR Prisma dana amurang. Jurnal Riset Ekonomi, Manajemen, Bisnis, dan Akutansi. Vol.4 No. 1. Hal. 1.330-1.339.

Merakati, Indah, Rusdarti, dan Wahyono. 2017. Pengaruh Orientasi Pasar, Inovasi, Orientasi Kewirausahaan, Melalui Keunggulan Bersaing Terhadap Kinerja Pemasaran. The Journal of Educational Development. JED 6 (2) (2017). Hal. 114-123. Universitas Negeri Semarang.

Pattipeilohy, Victor Ringhard. 2018. Inovasi Produk dan Keunggulan Bersaing: Pengaruhnya Terhadap Kinerja Pemasaran (Studi Pada Usaha nasi Kuning di Kelurahan Batu Meja Kota Ambon). Jurnal Maneksi. Vol. 7. No. 1. Hal. 65-73.

Prakosa, Bagas. 2005. Pengaruh Orientasi Pasar, Inovasi, dan Orientasi Pembelajaran Terhadap Kinerja Perusahaan untuk Mencapai Keunggulan Bersaing. Jurnal Studi Manajemen \& Organisasi. Vol. 2. No.1. Hal. 35-57.

Putra, I Gede Dharma, dan Rahanatha, Gede Bayu. 2017. Peran Inovasi Produk
Memediasi Orientasi Pasar Terhadap Kinerja Pemasaran. Universitas Udayana Bali. EJurnal Manajemen Unud. Vol.6 No.8. Hal. 4.361-4.390.

Sarjita. 2017. Pengaruh Orientasi Pasar dan Inovasi Produk Terhadap Kinerja Pemasaran pada Sentra Industri Kecil Pembuatan Bakpia di Kabupaten Bantu. Jurnal Bisnis, Manajemen, dan Akutansi. Vol. 4. No. 2. Hal 2737. 